\title{
Sugihara Shiro on Kawakami Hajime ${ }^{1)}$
}

\section{Kiichiro Yagi}

\begin{abstract}
:
In the last stages of his scholarly life, Sugihara Shiro (1920-2009) wished to collate his life's research on the history of economic thought in a four-volume work. The titles of these volumes were descriptive of not only his area of research but also his peculiar viewpoint applied in those areas. In the first volume, which is on Marx, Sugihara essentially viewed the essence of economy in the "economy of time," and appreciated Marx's unique insight of the dialectical relationship between necessary labor time and free disposable time. In the second volume, which is on John Stuart Mill, Sugihara considered Mill to be a sincere inquirer of human freedom, who anticipated the conditions of modern industrial society and mass democracy. The third volume deals with Kawakami Hajime, and the fourth volume, which was unpublished, is his investigation of modern Japanese economic thought using a bibliographical approach.

Kawakami Hajime (1879-1946) was a special figure in Sugihara's life. This is because Sugihara grew up in the academia of Kyoto, where Kawakami's influence still remained, and inherited Kawakami's moralistic views. This is seen also in Sugihara's study of Marx and John Stuart Mill.

In this essay, the author critically examines Sugihara's new interpretation of Kawakami's Bimbo Monogatari (Tales on Poverty) and suggests that the adoption of Marxism by Japanese intellectuals occurred under the influence of the Russian Revolution. In the author's view, this historical context overshadows the work of several generations of Japanese intellectuals, including Sugihara. Kawakami's moralist attitude did not change, even though he became a Marxist, and can be seen in his reflections on religious truth and scientific truth during his prison years. When Sugihara called Kawakami a "Man on Voyage," he seemed to be expressing his sympathy toward Kawakami's quest for truth in the difficult years of the twentieth century.
\end{abstract}

JEL classification numbers: B 14, B 51, N 35.

\section{Sugihara's Four Volumes of Work}

Entering in his eighties, with the blessing of his publisher, Fujiwara Shoten in Tokyo, Sugihara Shiro ${ }^{2)}$ devoted himself to editing his own work into four volumes. His plan

The History of Economic Thought, Vol. 54, No. 2, 2013. (C) The Japanese Society for the History of Economic Thought. 
was not so much about arranging his previous work into chronological order; rather, he wished to create an overarching work that would summarize his achievements in the four main fields of his research, to each of which he assigned one volume. ${ }^{3)}$ Thus, the titles of the four volumes of his works touch on the main themes of the work he wished to hand over to later generations.

Volume 1. The Essence of Economy and Labor: Studies on Marx

Volume 2. Liberty and Progress: Studies on John Stuart Mill

Volume 3. Learning and Humanity: Studies on Kawakami Hajime

Volume 4. Intellectual History and Bibliography: Studies on Japan

The first volume collects historical studies on Marx and Engels, as well as theoretical investigations into Marxian economics. Sugihara belonged to the camp of Marxian economists that had and still has considerable significance among economics academics in Japan. However, he was unique, in that he highly evaluated Marx's insights into the dialectical relationship between necessary labor time and free, disposable time. According to him, the distribution of time is the essence of economy, and it contains the true basis of human emancipation. Some reviewers differ in opinion from him on this point, on the grounds that Marx's advantage consists in his accurate description of capitalist economy as a specific historical system. What we would say here with regard to this first volume is that Sugihara had read Marx, Engels, and the classic and most recent Marxian literature from a humanistic view- point.

Sugihara's quest for the historical conditions that would emancipate the people is more apparent in his investigations into John Stuart Mill. His first book, J. S. Mill and Marx (1957), was published by Minerva Shobo in Kyoto. Despite Marx's somewhat sarcastic comments with regard to Mill, Sugihara treats Mill as a sincere inquirer of human freedom who anticipated today's modern conditions of an industrial society and mass democracy. In 1980, he published a well-read text entitled J. S. Mill and the Moderns, published by Iwanami Shoten. In the second volume of the Works, we see a more accurate description of Mill, as it contains a broader range of his studies within the context of the intellectual history of British economic thought.

While the first and second volumes of the Collected Works were published in 2003, soon after an announcement regarding a publication plan for it, we had to wait another three years before the third volume appeared. As of the time of writing, the fourth volume has not yet appeared, although Sugihara had left the bulk of the manuscript for it on his work desk when he died in July 2009.

Sugihara explains that the delay in the publication of the third volume resulted from his rereading of Kawakami's Autobiography, whereupon he realized the significance of Kawakami's reflections on the strained relationship between "scientific truth" and "religious truth" during his five years in prison; Sugihara endeavored to trace Kawakami's lifelong inquiry from this viewpoint. To discuss Kawakami's thought in this last stage, Sugihara added a new part to the third volume, "Religion and Science in Kawakami 
Hajime." However, it appears that Sugihara's remaining energy was insufficient to complete this task: this new part is not rich in content and occupies only 30 of the over 500 pages in this volume.

Many researchers, including the author of this essay, feel a lack on account of this missing fourth volume. Sugihara was one of the founders of the historical study of modern Japanese economic thought. In particular, his investigations of the economic literature of the first century from the Meiji Restoration and collections of biographies of leading figures in the modernization of Japanese economy have been of great benefit to all his colleagues and followers. He investigated into numerous economic journals in the Meiji and Taisho era that had considerable influence over the public at that time but been often forgotten at present.

It was Sugihara who introduced the bibliographical approach to the history of economic thought and successfully achieved collaboration among researchers and librarians/archivists. Regrettably, as for this missing fourth volume, we might need to understand and appreciate the overwhelming difficulties inherent in amalgamating such writings into a single volume, and admit that the volume may never be forthcoming.

In the following two sections, we focus on Sugihara's studies of Kawakami Hajime. ${ }^{4}$ Since, in our view, the whole of Sugihara's corpus has its origins in Kawakami, his views on Kawakami will reveal some core issues that this sincere researcher of the history of economic thought was compelled to face in his time. ${ }^{5)}$

\section{Kawakami Hajime in the History of Japanese Economic Thought}

Kawakami Hajime (1879-1946) was a special figure to Sugihara, who studied at the Kyoto University (then Kyoto Imperial University) in the war years, more than a decade after Kawakami had left it. Under the strict controls of the war years, he could not read Kawakami's books before being allowed to use the library of his mentor, one of Kawakami's students. When the war ended with the defeat of Japan, Sugihara became an assistant staff member of the Economics Faculty of the Kyoto University. As criticism increased against the attitude of this Faculty in the war years following Kawakami's leave (i.e., expulsion) in 1928, its new dean decided to collect the resignations of all the full professors who had been responsible for managing the Faculty. According to the original intention of this new dean, a younger generation of associate professors, lecturers, and assistant staff members who had not been involved in supporting the war effort should form the core of the newborn Economics Faculty. However, some of them resigned on their own volition and moved to other universities; Sugihara was among them.

Some of Sugihara's viewpoints in his studies of the history of economic thought may have their origins in Kawakami’s work; after all, it was Kawakami who had dealt with J. S. Mill in his Shihonshugi Keizaigaku no Shiteki Hatten (Development of the Economics of Capitalism) (1923), at a pivotal time of turning from a naïve support of capitalism to a conscientious reflection of the social problems under capitalism. Further, I as- 
sume, Sugihara's view of the essence of economy shares similarities with Kawakami's view of labor value as "the sacrifice of [the] human species." ${ }^{6)}$

To understand the main topics Sugihara dealt with in his Kawakami studies, we can refer to the contents of the third volume of the Works. This volume consists of five parts:

I. Kawakami Hajime in the History of Japanese Economic Thought

II. Progress in the History of Japanese Economic Thought and Kawakami Hajime

III. Kawakami Hajime, a Man on Voyage

IV. Science and Religion in Kawakami Hajime

V. The Way towards the Collected Works of Kawakami Hajime

The first two parts have similar titles; the first part positions Kawakami and his main works within the context of the history of economic thought in Japan and summarizes Kawakami's views on labor, the population problem, the agricultural problem, and the history of economic thought. This part is accessible to the general public who would know of the significance of Kawakami and his thoughts vis-à-vis modern Japan. On the other hand, the second part seems to be oriented to the professional interests of researchers of the history of economic thought-especially those who are accustomed to examining an economist's thinking within the context of the influence of and confrontation with other origins or economists. ${ }^{7)}$ Thus, the second part deals with Kawakami's reception of Western econom- ics, as well as with his two decades of relations with his rival Tokuzo Fukuda (1874-1930), a leading economist of the time. It is noteworthy, at this point, to say that Sugihara followed Fukuda, who had named his own generation as being in the fourth period in the development of Japanese economics. In Fukuda's view, the preceding three periods were as follows: the period of the introduction of Western economics; the period of its application to Japan, and enlightenment; and the period of the introduction of German economics. The fourth period, ostensibly, would be that which saw the creation of its own theory in dealing with new problems that appeared in the course of domestic economic development and the deepening of international relations.

Fukuda started his career under the influence of German Historical economics; he arrived at his own welfare economics, which are grounded on the generally approved rights of the living. Like Fukuda, Kawakami experienced several turns in his inquiries, but arrived at a different destination: Marxism. Kawakami chose this destination as a result of his ardent desire to solve the fundamental social problems of Japan. Although Fukuda was five years older than Kawakami, the former admitted that the latter was a fellow rival economist who shared the common task of establishing his own economics in Japan. Sugihara followed several debates between the two, from the early period until Fukuda's abrupt death in 1930. Following Kawakami's turn to Marxism, the relationship between the two economists changed from one marked by friendly discussion to one of sharp antagonism. Still, Fukuda revealed his solidarity with Kawakami in 1928 by criti- 
cizing Kawakami's expulsion from the Kyoto University under the pressure of the Ministry of Education (Fukuda 1928). On the other hand, when Fukuda died abruptly in 1930, Kawakami praised Fukuda as "the most able and most knowledgeable bourgeois economist that Japan had ever had." (p. 271)

Kawakami's praise, it appears, is indeed valid, since at present Fukuda is generally considered the most influential origin of various streams of non-Marxian economics in Japan. However, it was Sugihara who left a pioneering work that interprets Fukuda within the contemporary context, which included Kawakami. He appreciated the discussions between the two economists, despite their differences in their final ideological destinations. ${ }^{8)}$

\section{Kawakami, a Man on Voyage}

The third part is a rearrangement of a book that Sugihara published in 1996 through Iwanami Shoten, Tabibito, Kawakami Hajime (Kawakami Hajime, a Man on Voyage). This title derives from Kawakami's Japanese verse in his final years. Here we confess the difficulty of selecting an appropriate English term for the original Japanese tabibito. The literary equivalent may be "traveler" or "tourist"; however, in the tradition of Japanese literature, tabibito refers to a man who is traveling in order to discover the truths of life. The famous poets Saigyo of the 11 th century and Basho of the 18th century produced most of their poetry works in their respective travels. From a religious viewpoint, the term shares aspects similar to "pilgrim"; however, neither Saigyo nor Basho had a destination in mind. Rather, they wished to die while traveling. Thus, we apply the term "voyage," to refer to Kawakami's lifelong quest for long travels.

Sugihara also references Kawakami's Chinese verse, which he crafted as a farewell to the traveling life. In this verse, Kawakami speaks of his life as if it were a boat not bound by rope to a harbor. Then, Sugihara introduces interpretations by a specialist in Chinese classics-namely, Prof. Ikkai Tomoyoshi, also a Kawakami fan-who states that the image of the unbound boat connotes both unrest and the anticipation of freedom. We suppose that Prof. Sugihara and Kawakami shared similar, retrospective impressions of their respective lives, in their final years.

Sugihara explains, as follows, why he calls Kawakami “a man on voyage”:

Other than that of a scholar, Kawakami had various aspects of life such as that of a patriot, a man of letters, and a truth seeker. It is the nature of Kawakami that all these features existed not separately but were combined in one, in Kawakami. Being such a person, Kawakami had to be a man on voyage from the beginning up to the end of his life. (p. 290)

The meaning of this last sentence is somewhat ambiguous. Sugihara would likely say that in Kawakami, the voyage of the researcher, that of one engaged in politics, and that of the truth seeker are amalgamated into one.

This part contains several topics, including his encounter with early socialism, including Tolstoy; his patriotism, as revealed in his travel essays Sokoku wo Kaerimite (Looking Back at the Home Land) (1916); and his appreciation of British culture and 
society. However, the most important topics are those pertaining to his novel interpretation of Kawakami's intention in the Bimbo Monogatari (Tales on Poverty) (orig. 1916) ${ }^{9)}$ and to his route to Marxism under the impact of the Russian Revolution.

How we should understand and assess the Bimbo Monogatari is a topic that appears repeatedly in this volume. This work became problematic, because it suggests three measures for the solution of poverty (restraint of luxurious consumption by the rich, remedying the gap between the rich and the poor, and reorganizing present economic institutions that are based on private profit-making); however, in his final recommendation, he adopts the first measure and declines the other two. This choice is generally considered a manifestation of Kawakami's moralist traits, in his view of socioeconomic affairs.

Sugihara challenges the authenticity of the choice itself by focusing on Kawakami's speech at a meeting of business people in Osaka; this meeting was held half a year before he started the series of articles that would comprise the Bimbo Monogatari, which were published in the Osaka Asahi Shimbun (an influential newspaper). It bore the title "Hinkon" ("Poverty"). Further, Sugihara discovered a private memorandum for a speech entitled "Utsutsu no Yo yori Yume no Kuni he" ("From the Real World to the Dreamed World"), dated from the same period and containing similar content. Sugihara's interpretation is that institutional reorganization-namely, the third measure, which virtually implies a socialist system-was the real solution in Kawakami's original plan, but that for some reason he refrained from publishing it.
As for why the voluntary restraint of luxury consumption by the rich took "front stage," Sugihara avoids final judgment. He proposes only a hypothesis: "in the process of continuing the series, Bimbo Monogatari, such a consciousness that a fundamental conversion in the view of economy, moral, and humanity should precede the fundamental conversion of a system as its precondition might have grown in him" (p. 334).

This was a novel interpretation that shocked those who had taken the published text of the Bimbo Monogatari literally. However, the author of this essay is not persuaded by Sugihara's reasoning, for two reasons. First, in the Bimbo Monogatari, the solution of restricting luxury consumption was derived logically from Kawakami's theoretical explanation of the crowding out of the demand for necessary goods by the demand for luxury goods. Thus, it is difficult to believe that this measure was used to camouflage a true solution. Second, indeed, a view similar to Sugihara's hypothetical interpretation, i.e., a collateral or preconditioned view of moral revolution in relation to system revolutionappeared in Kawakami’s 1921 article entitled "Mental Revolution and Material Revolution." However, it is risky to extrapolate this view from Kawakami's writing of five years previous.

Further, we cannot neglect the second measure, which Sugihara seems to consider relatively less significant. It suggests a radical redistribution by the state to remedy the gap between the rich and the poor; this is the policy generally favored by the supporters of social policy. We know that Kawakami in these years had been trapped in two sets of collateral antagonisms, between egoism and 
altruism and between productive policy and distributive policy. He considered this productive policy as aligning with Adam Smith's approval of self-love, and he sought for a new economics that could vindicate a distributive policy that is oriented to the attainment of distributive justice.

It was in 1920 that Kawakami abandoned the second measure, by omitting it when reusing the text of the Bimbo Monogatari in his new publication Shakai Mondai Kanken (Glimpses over Social Problems). In my view, this omission serves as an indicator that Kawakami had finally left the socialpolicy camp. In other words, until 1920, even if Kawakami should have imagined a socialistic institutional revolution, in terms of social policy, it had not been clearly distinguished in his mind from a radical measure. Thus, we are left with the impression that Sugihara assessed Kawakami in the period of writing the Bimbo Monogatari (i.e., amidst World War I), as well as Kawakami's reflections from the later development of his thought.

Bimbo Monogatari had appeared originally as a series article in the influential newspaper Osaka Asahi Shimbun, from September to December 1916. In March 1917, it was published as a book by Kobundo, Kyoto; there were 30 printing editions before the author ordered in 1919 a cease to its printing. The period between its publication and the cease in 1919 was when the impact of the Russian Revolution gradually penetrated the minds of Japanese intellectuals. Of course, Sugihara did not fail to place Kawakami's adoption of Marxism in the contemporary context, following the Russian Revolution. The following were dealt with, one by one: criticism leveled against him by Kushida Tamizo and Fukumoto Kazuo, leftist students with whom he had had relations in Kyoto since 1924; a quarrel with a colleague professor in ethics in Kyoto, Watsuji Tetsuro, regarding the students' movement in 1926; and his emphasis on the "period of mental preparation" in transition periods and in the socialist revolution. These points are thought to have occurred to him during the time of the Russian Revolution. We then face a counterfactual question: If the Russian revolution had not yet occurred, had Kawakami adopted spontaneously that ideology now known as Marxism?

Kawakami is not the only individual about whom this question is asked similary in this respect. Many Japanese academicsin particular, economists-adopted Marxism in the 1920s and early 1930s; thus, this is a question that may ultimately touch upon the intellectual independence and theoretical consistency of Marxism in Japan, in all fields within the social and human sciences. ${ }^{10)}$

Sugihara points out that in 1920 and 1921, Kawakami deepened his understanding of socialism and social revolution, and also discussed the relationship between socialism and the freedom of individuals, mental preparations to be undertaken prior to socialist revolution, the "development of thought," and the nature and form of labor under socialism. These topics reveal that Kawakami retained his moralistic interest in the mental attitudes of man, even after becoming a Marxist.

At the close of this part, Sugihara cites the enigmatic words of another leading historian of economic thought in Japan, Uchida Yoshihiko: "But Kawakami now cannot rest 
peacefully" (p. 373). We interpret this as a criticism of the (once-existing) socialism that had once so influenced leftist intellectuals, including Kawakami in his final stage of work.

\section{Science and Religion in Kawakami Hajime}

Sugihara regards the quest for both scientific truth and religious truth as Kawakami's lifelong task (p. 415). However, the relationship between these two truths was, he states, not discussed in A Man on Voyage, and inquiries had yet to be made.

Following his arrest in 1933, Kawakami was deprived of any possibility of continuing his research in economics. No writing was allowed in prison, save for that consistent with conversion. Kawakami chose to write about his mental history after he had encountered teachings pertaining to the absolute negation of selfishness in Christianity. $\mathrm{He}$ wrote that he had had a supernatural experience when he had devoted himself to the religious service of shedding his selfishness. He confessed that he believed in the existence of religious truth, besides scientific truth. These writings were included in the posthumous publication of Kawakami's $\mathrm{Au}$ tobiography; however, given the fact that they originated under such coercive circumstances, they have not been taken seriously by researchers.

In the Kawakami volume of his Works, Sugihara set aside a special part that touches on these two truths. This part contains Sugihara's explanations for several of Kawakami's prison writings, the introduction of existing views on this matter, and six appendices of related literature. However, instead of providing a final conclusion, Sugihara writes as follows:

Kawakami imposed on himself the task of clarifying the difference and relation between scientific truth and religious truth. This task is not limited to such Marxists as Kawakami, and not only to the disciples of particular religions such as Christianity or Buddhism. It is a problem for the moderns who face the need for a fundamental change in the society. In prewar years in Japan, it was really a focusing point that attacked the most vulnerable points of the ruling state's authority. Kotoku Shusui, Noro Eitaro, Iwata Yoshimichi, Yamamoto Senji, and others died due to their brave attack. In prison, Kawakami took this problem as his central theme-that is, of having a value equivalent to his life. (p. 441 ff.)

In this Kawakami volume, Sugihara defines the 15 or so years following Kawakami's arrest as the time of his third stage of thought; as such, he treats it as being independent from the first stage (that of a devoted researcher) and the second stage (that of a Marxist engaged in politics). Sugihara's final assessment of Kawakami's value in relation to the intellectual history of Japan seems to favor Kawakami in this final stage. Still, Sugihara writes modestly, that he wishes to continue his inquiry and attain a final outcome.

The final part of the volume collects his writings that have bibliographical value within the realm of Kawakami studies. "Concise Introduction to the Bimbo Monogatari" shows Sugihara's view of the Bimbo Monog- 
atari, prior to his novel interpretation; this is very informative of how this work had been attentively constructed for lay readers of a mainstream newspaper. Other writings that relate to the editorial work of the Kawakami Works are also valuable. This Works would not have been realized without Sugihara's devotion to it.

Kiichiro Yagi: Setsunan University

\section{Notes}

1) In the main text, I follow the Japanese custom of placing family names first. In writing this essay, I make use of my previous review (in Japanese) of Sugihara's Kawakami studies (Yagi 2007).

2) Sugihara was born in 1920 in Kyoto and died in 2009. He studied at the Third High School and the Kyoto Imperial University, successively. Upon graduation in 1942, he became an assistant staff of his alma mater. He taught at Kansai University (1948-70) and Konan University (1970-85). His publications in Japanese include J. S. Mill and Marx (Kyoto: Minerva Shobo, 1957), Making of Marx's Economics (Tokyo: Mirai-sha, 1960), Western Economics and Modern Japan (Tokyo: Mirai-sha, 1972), History of British Economic Thought (Tokyo: Miraisha, 1973), Principles of Economics (Tokyo: Dobunkan, 1973), Economic Journals in Japan (Tokyo: Nihon Keizai Hyoronsha, 1987), Tabibito, Kawakami Hajime (Tokyo: Iwanami Shoten, 1996), and Mill, Marx, and Engels (Tokyo: Sekai Hyoronsha, 1999), among others. He was the editor of numerous academic publications in the field of the history of economics. He was also known as a voracious reader of the most recent literature in his research fields. For his bibliographical works, he was honored by the third Mozume Award. He served as a representa- tive of the Memorial Society of Kawakami Hajime from 1981 to 1992, and he endeavored to publish Kawakami's Collected Works, through Iwanami.

3) Sugihara made the most of any author's privilege to rearrange and rewrite his or her own previous writings. Thus, to know the real form and the original reception of his works, we need to look back at the original publication.

4) For readers who cannot read the Japanese language, a biography of Kawakami by G. L. Bernstein (1976), which was translated into Japanese in 1991, is recommended.

5) We do not assert that our view excludes different views of Sugihara's works. It is unclear just how deeply Sugihara, in his early stage of investigation, had a conscious affinity for Kawakami.

6) Kushida Tamizo, a Kawakami's disciple and rival, characterized moralist traits in his mentor's understanding of Marxian value theory with this term. However, Sugihara finds the essence of time economy in Kawakami's peculiar view of value theory (Works vol. 3, p. 459).

7) In this essay, the term "history of economic thought" refers to both the real, historical development of economic thought and to the special research discipline in this field. I ask that readers carefully discern which of the two meanings is applicable to each occurrence of this term.

8) In an article coauthored with Takutoshi Inoue (Inoue and Yagi 1998), I followed Sugihara's suggestion and compared Kawakami and Fukuda.

9) Bimbo Monogatari (Tales on Poverty) was written first as a series of articles in the influential popular paper Osaka Asahi Shimbun, from September 12 to December 26, 1916. In the next year, it was amalgamated and published in book form by Kobundo, Kyoto. This text begins with a remark on the 
urban poverty seen within the capital cities of affluent Western nations; it also discusses the state and origin of, as well as the remedy for, this poverty, citing Western literature and Chinese classics alike. This book, then a bestseller that was printed 30 times, exerted considerable influence on Japanese trends. Recently, its influence on Chinese intellectuals has been investigated (Mita 2003).

10) The author of this essay confesses that he, too, belongs to the stream of Marxian economics in Japan. Following the collapse of the "(once) existing socialism," he himself questioned the extent and nature of the influence of Marxism in economics, as a kind of social phenomenon. See Yagi (1992).

\section{References}

Bernstein, Gail Lee. 1976. Japanese Marxist: a portrait of Kawakami Hajime, 1879-1946. Cambridge, MA: Harvard Univ. Press.

Fukuda, Tokuzo. 1928. Fue fukazaru ni odoru: Ronoto no kaisan to daigaku no appaku (Dancing without accompanying music: Disbandment of the Rodo-Nomin Party and the pressure over universities). Tokyo Asahi Shimbun, April 24-May 8, 1928.

Inoue, Takutoshi and Kiichiro Yagi. 1998. Two Inquirers on the Divide: Tokuzo Fukuda and Hajime Kawakami. In Economic Thought and Modernization in Japan, edited by $\mathrm{S}$.
Sugihara and T. Tanaka. Cheltenham, UK: Edward Elgar.

Kawakami, Hajime. 1917. Bimbo Monogatari (Tales on Poverty). Kyoto: Kobundo.

—. 1982-1986. Kawakami Hajime Zenshu (Collected Works), 36 vols. Tokyo: Iwanami Shoten.

Mita, Takeshi. 2003. Yomigaeru Kawakami Hajime: Kawakami Hajime to Kindai Chugoku (Reviving Kawakami Hajime: Kawakami Hajime and Modern China). Tokyo: Fujiwara Shoten.

Sugihara, Shiro. 1980. John Stuart Mill to Gendai (John Stuart Mill and the Moderns). Tokyo: Iwanami Shoten.

- 1996. Tabibito, Kawakami Hajime (Kawakami Hajime, A Man on Voyage). Tokyo: Iwanami Shoten.

_. 2003- . Sugihara Shiro Chosakushu (Works of Sugihara Shiro) (2003- ), 4 vols. Tokyo: Fujiwara Shoten.

Yagi, Kiichiro. 1992. Mondai to shiteno Marx Keizaigaku (Marxian Economics as a question). In H. Mochida et al. Shijo to Kokka (Market and State). Tokyo: Bokutaku-sha. - 2007. Sugihara Shiro Chosakushu vol. 3, Gakumon to Ningen: Kawakami Hajime Kenkyu (Review: Collected Works of Sugihara Shiro, vol. 3: Learning and Humanity: Studies on Kawakami Hajime). Keizai Ronshu (Kansai University) 57 (2). 